\title{
Віктор РУСІH
}

\section{ПІДВИЩЕННЯ СТИМУАЮЮЧОГО ВПАИВУ ПРИВАТНИХ ГРОШОВИХ ПЕРЕКАЗІВ 3-ЗА КОРДОНУ}

З'ясовано причини надходження приватних грошових переказів в Україну та визначено основні фрактори, що впливають на їх обсяги. Проаналізовано динаміку надходжень приватних грошових переказів в Україну з-за кордону за країнами, каналами надходження та джерелами формування. Досліджено вплив грошових переказів на соціально-економічне середовище в Україні. З'ясовано позитивні та негативні наслідки для домогосподарств і держави від грошових переказів. Визначено найважливіші завдання макроекономічної політики України щодо використання грошових переказів з-за кордону в інтересах усього суспільства.

Ключові слова: грошові перекази мігрантів, витрати домогосподарств, доходи домогосподарств, міжнародна міграція.

\section{Виктор РУСИН}

Повышение стимулирующего влияния частных денежных переводов из-за границы

Определены причины поступления частных денежных переводов в Украину и отмечены главные фракторы, влияющие на их объемы. Проанализирована динамика поступлений частных денежных переводов в Украину из-за границы в разрезе стран, каналов поступления и источников фрормирования. Исследовано влияние денежных переводов на социально-экономическую среду в Украине. Выяснено позитивные и негативные последствия для домохозяйств и государства от денежных переводов. Определены важнейшие задачи макроэкономической политики Украины касающиеся использования денежных переводов из-за границы в интересах всего общества.

Ключевые слова: денежные переводы мигрантов, расходы домохозяйств, доходы домохозяйств, международная миграция.

\section{Viktor RUSIN}

\section{Increase of stimulant influence remittances from abroad}

Introduction. International migration is accompanied by strong financial flows, which are formed due to money transfers of migrants. Ukraine is one of the largest suppliers of labours to the countries of the European Union and other countries and, in accordance with it, it is one of the largest recipients of remittances. 
The purpose of this article is to investigate the impact of remittances of citizens from abroad on the socio-economic environment in Ukraine and to develop recommendations for improving their use for the benefit of society as a whole.

Results. It's found out the reasons of the transfer of private money to Ukraine and the main factors influencing their volumes are determined. The dynamics of remittances of private money transfers to Ukraine from abroad is analyzed. It is ascertained that money transfers from Ukrainian migrants are significant, their volumes make up about $6 \%$ of GDP. The influence of remittances on the socio-economic development of Ukraine is researched. It is noticed positive and negative consequences for households and the state from remittances. It has been established that remittances are significant additional income of households and are mainly spent on consumption. Their positive impact on gross national income, balance of payments, welfare of the population, poverty level, unemployment rate is argued.

Conclusion. In order to use remittances from abroad in the interests of the entire society as a motive for social and economic development, a focused and effective migration policy of the state is needed. One of the most important tasks of the macroeconomic policy of Ukraine should be the creation of such conditions that migrant remittances should be received by official channels and used not only for consumer purposes, but also for investing.

Keywords: migrant remittances, household expenses, household incomes, international migration.

JEL Classification: J11, J15, J61, O15.

Постановка проблеми. Впродовж останніх років міжнародна міграція супроводжується потужними фрінансовими потоками, які формуються завдяки грошовим переказам мігрантів з-за кордону. В ООН стверджують, що на початок 2017 р. налічувалося близько 244 млн людей, які перетнули міжнародні кордони в пошуках "кращого життя" [1]. Це становить приблизно 3,5\% чисельності населення світу загалом. Близько 65 млн людей були вимушені залишити свої домівки, втікаючи від насилля і переслідувань, та стали біженцями. За даними Світового банку, у десятку провідних країн джерел міграції увійшли Індія, Мексика, Росія, Китай, Бангладеш, Пакистан, Філіппіни, Афрганістан, Україна та Великобританія [2]. Міжнародні економічні інститути відводять Україні дев'яте місце у світі серед країн з середнім рівнем доходу, які отримують грошо- ві перекази, та перше місце у Східній Європі і колишньому Радянському Союзі [3].

Україна $€$ одним із найбільших постачальників робочої сили до країн Європейського Союзу та інших держав. Враховуючи складну соціально-економічну та політичну ситуацію в Україні, все більша кількість населення країни мігрує за кордон з метою коротко- чи довгострокового працевлаштування. За статистичними даними, які наводять демографи, з України на заробітки виїхало від 10 до 20\% економічно активного населення. Значна частина українців емігрує лише на сезонні роботи. Попри те, що частина зароблених за кордоном коштів витрачається на споживання в країні перебування, велика їх частина надходить в Україну. Надходять грошові перекази і від громадян інших країн, що обумовлено наявність родинних зав'язків з громадянами України. 
Аналіз останніх досліджень і публікацій. Дослідженню теоретичних і практичних питань надходження грошових переказів громадян в Україну та їх використанню присвячено праці багатьох вітчизняних науковців і практиків, зокрема: А. Гайдуцького [4], Е. Лібанової [5], О. Малиновської [6; 7], В. Толуб'яка [8] та ін. Незважаючи на значну увагу до окресленої проблематики, актуальними залишаються подальші наукові дослідження, спрямовані на вивчення складу та динаміки грошових переказів громадян в Україну, виявлення наслідків їх впливу на соціально-економічне середовище та вдосконалення механізмів їх залучення в розвиток економіки країни.

Метою статті $€$ дослідження впливу грошових переказів громадян 3-за кордону на соціально-економічне середовище в Україні та вироблення рекомендацій щодо покращення їх використання в інтересах усього суспільства.

Виклад основного матеріалу дослідження. Суттєві економічні наслідки міжнародної трудової міграції спричинюють грошові перекази мігрантів. У країнах-одержувачах вони $\epsilon$ джерелом формування економіки країни, оскільки доходи населення збільшуються за рахунок трансфертів мігрантів. Джерелом інформації для аналізу обсягів грошових переказів мігрантів в світовій практиці $є$ дані центральних банків. Проте окремі країни такої статистики взагалі не ведуть. У деяких країнах не враховують перекази через небанківські установи, зокрема поштові перекази. Фактично неможливо достовірно визначити обсяги грошових переказів неформальними і необлікованими каналами, а також у натуральній формі. Тому, використовуючи дані щодо грошових переказів мігрантів, варто мати на увазі, що насправді їх обсяги можуть бути значно меншими чи більшими.

Обсяги грошових переказів залежать від багатьох фракторів. Насамперед - від кіль- кості мігрантів. На обсяги переказів також суттєво впливають тривалість перебування за кордоном, розміри заробітку мігрантів, обсяги витрат на споживання та проживання в країні перебування, сімейний статус, вік, фрінансова забезпеченість залишених на батьківщині родичів, намір повернутися тощо.

У Світовому банку зазначають, що найбільшим джерелом грошових переказів $€$ США. Обсяг коштів, відправлених із цієї країни в 2014 р. - 56 млрд дол. Далі за величиною перерахованих громадянами коштів за межі країни визначені Саудівська Аравія 37 млрд дол, Росія - 33 млрд дол. Найбільшим одержувачем грошових переказів були країни зі значною чисельністю населення, які $€$ постачальниками мігрантів: Індія обсяг коштів, що надійшли в цю країну в 2015 р., - 72 млрд дол., Китай - 64 млрд дол. і Філіппіни - 30 млрд дол. [2]. Попри значно менші абсолютні суми відносно ВВП, перекази є найбільшими в низці невеликих країн, 3-поміж яких лідирують Таджикистан, Ліберія, Киргизстан, Лесото й Молдова. Перекази до цих країн співставні з чвертю чи майже половиною ВВП цих країн [6, с.7].

За різними даними, щороку українські мігранти перераховують на батьківщину кошти, обсяг яких становить приблизно 10\% від ВВП України. В офріційних статистичних даних НБУ зазначено, що приватні грошові перекази домогосподарствам України з інших країн були максимальними в 2013 р. і становили майже 8,5 млрд дол. (4,5\% ВВП) [9]. У 2016 р. цей показник знизився до 5,4 млрд дол. (5,8\% ВВП). Перелік країн, із яких в Україну надходять грошові перекази впродовж останніх років, залишається незмінним. Незважаючи на складні та напружені відносини з Росією, останніми роками в Україну найбільше коштів від емігрантів надходить саме з цієї країни. Проте з кожним роком обсяги переказів з Росії суттєво зменшуються. Якщо у 2014 р. із Росії в 
Україну надійшло більше 2 млрд дол. переказів, то у 2016 р. - менше 1 млрд дол. У 2016 р. приватні перекази з Росії становили більше 20\% від загального обсягу переказів в Україну. До трійки лідерів за переказами в Україну належать також США та Німеччина. Із країн Європейського Союзу надійшло 1,8 млрд дол., що становить 41,1\% від загального обсягу грошових переказів. У більшості країн, з яких в Україну надходять приватні грошові перекази, обсяги таких переказів щороку зростають.

Приватні грошові перекази в Україну надходять через банківську систему (рахунки в банках), міжнародні платіжні системи та неформальними каналами. За офіційними даними НБУ, у 2016 р. в Україну найбільше приватних переказів надійшло через банківську систему. Порівняно із попереднім роком, обсяги цих переказів зросли на 13,6\% до 2,3 млрд дол. Їх частка в загальному обсязі переказів становила 42\% (рис. 1) [9]. Дещо менше коштів перераховано в Україну із використанням міжнародних платіжних систем, надходження яких залишилися май- же на рівні попереднього року і становили 2,1 млрд дол. За оцінками НБУ, обсяги коштів, що надійшли в Україну неформальними каналами (шляхом передавання готівки або матеріальних цінностей від одного домогосподарства іншому), у 2016 р. становили понад 1 млрд дол., або 18,8\% від загальних обсягів грошових переказів в Україну.

Фахівці світового банку стверджують, що сума неофіційних переказів може становити від чверті до половини тих, що обліковуються. Окремі науковці зауважують, що грошові перекази в Україну неформальними каналами значно більші, ніж наводить НБУ. Зокрема А. Гайдуцький зазначає, що міграційний капітал сягає 25,6 млрд дол. щорічно [4]. Отже, реальні обсяги грошових надходжень від працівників-мігрантів з-за кордону вірогідно можуть бути значно більшими, ніж обсяги приватних трансфертів, відображених у статистичних даних, зокрема НБУ.

Проаналізувавши структуру приватних грошових переказів за джерелами їх фрормування, зауважимо, що у 2016 р. як оплата праці робітників, які працюють за

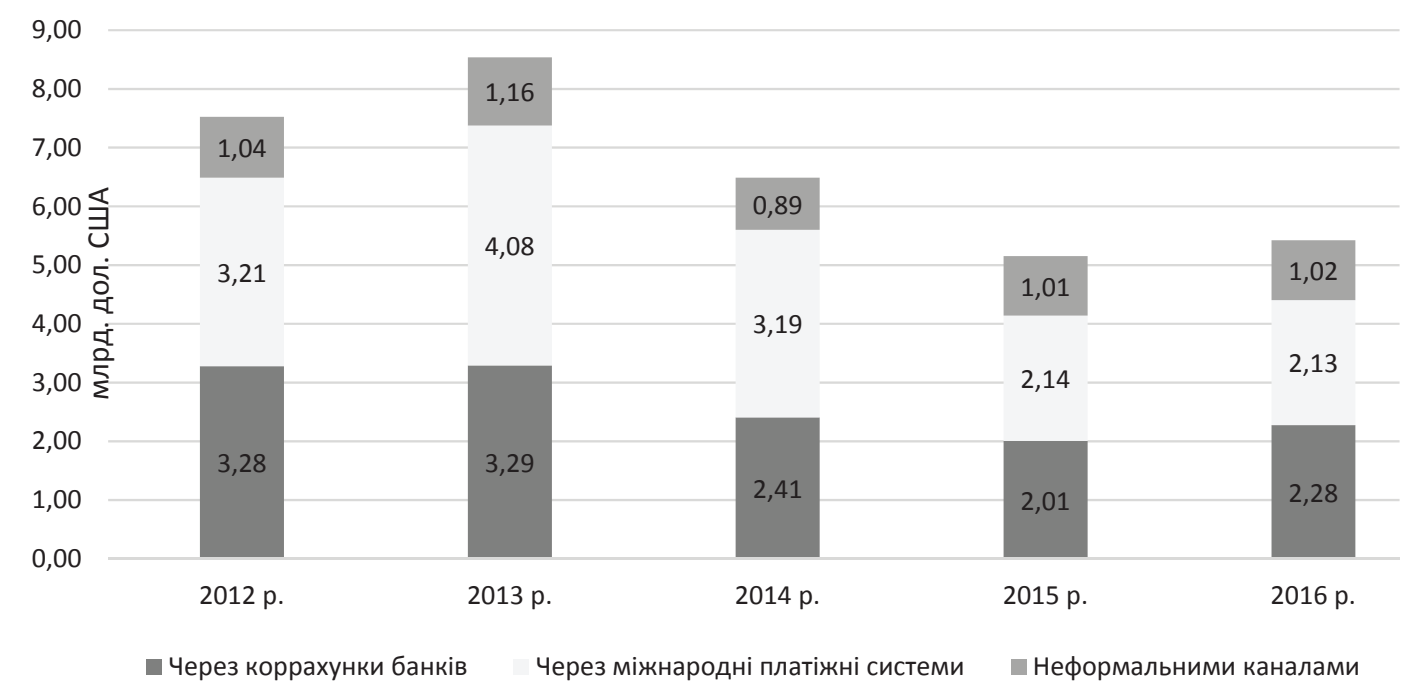

Рис. 1. Обсяги приватних грошових переказів в Україну за каналами надходження у 2012-2016 рр. 
кордоном менше року, в Україну надійшло 3,6 млрд дол., що становить 66,4\% усіх переказів. Дещо менше коштів переказали робітники, які працюють за кордоном понад один рік. У структурі приватних переказів на інші приватні трансферти у 2016 р. припало 0,7 млрд дол., що становить 13,3\% усіх переказів.

Масштаби та динаміка грошових переказів мігрантів в Україну підтверджують доцільність дослідження їх впливу на соціально-економічне середовище. Коректне оцінювання соціально-економічних наслідків для країн-донорів та країн-реципієнтів від міжнародної трудової міграції $€$ доволі складним завданням. Визначаючи ефект для соціально-економічного розвитку України від грошових переказів емігрантів, доцільно враховувати всі наслідки від надходження таких переказів.

Серед дослідників спостерігається неоднозначність поглядів щодо позитивного чи негативного впливу грошових переказів у країнах походження та країнах призначення мігрантів. У науковій літературі дискутуються три основні напрями впливу переказів:

1) на добробут домогосподарств, рівень бідності і майнове розшарування;

2) на зайнятість, виробництво та економічний розвиток;

3) на скорочення дефіциту торговельного та платіжного балансу [6, с. 15].

Економічні наслідки для України від грошових переказів можна аналізувати на мікрорівні (ефект для домогосподарств) та макрорівні (ефект для держави). На мікрорівні сім'ї емігрантів, які залишились на батьківщині (домогосподарства), отримують грошові надходження, які витрачають на свої потреби (поточне споживання). Домогосподарства, окрім витрат на житло та продукти харчування, можуть дозволити собі витрати на придбання нерухомості та товарів тривалого використання, на освіту, відпочинок. Частину коштів, заощаджених у результаті регулярного отримання переказів, домогосподарства можуть спрямувати на розвиток підприємництва, тим самим зменшивши свою залежність від подальших переказів з-за кордону.

Однак можна виокремити і певні негативні наслідки для домогосподарств від грошових переказів їх членів, які тимчасово чи постійно перебувають за кордоном. Насамперед, це - зниження мотивації решти членів домогосподарств до працевлаштування на батьківщині за невисокі розміри оплати праці, порівняно із отриманими переказами. Знижується і мотивація у дітей до хорошої успішності у навчанні. Особливо це виявляється у випадках міграції матерів. У домогосподарствах, особливо молодші члени, орієнтуються на подальшу міграцію.

Грошові перекази є основним джерелом доходів членів домогосподарств на батьківщині. Отримуючи їх, громадяни втрачають інтерес до економічної та політичної ситуації в країні. Втрачається мотивація до контролю за діяльністю публічних органів влади. Як наслідок, керівництво держави, яке не спроможне забезпечити гідне життя населення, гальмує реформи в країні та частково зменшує свою відповідальність за це.

На рівні держави міжнародні грошові перекази емігрантів - це приплив додаткових коштів, які, залежно від їхнього обсягу, можуть впливати на економічне зростання, національний дохід, ВВП, платіжний баланс, ринок праці тощо. Ефект від грошових переказів трудових емігрантів виявляється по-різному в кожній країні, залежно від розвитку ії̈ економіки, рівня бідності та доходів населення. В Україні отримані перекази витрачаються переважно на забезпечення споживчих потреб домогосподарств та на придбання товарів тривалого використання. Таким чином, грошові пере- 
кази сприяють зниженню рівня бідності в країні. Однак такі доходи домогосподарств сприяють посиленню нерівності доходів населення. Чим більшою була майнова нерівність населення країни, тим більше вона посилюється надходженнями грошових трансфрертів 3-за кордону.

Під впливом грошових переказів з-за кордону змінюється і структура витрат домогосподарств. Вони поступово спрямовують меншу частку доходів на харчування й інші поточні витрати, а більшу - на освіту, лікування, відпочинок, придбання товарів тривалого використання [5]. Погоджуємось із твердженнями науковців, що певні виклики виникають саме у зв'язку з внесками переказів у накопичення людського капіталу. В Україні забезпечене заробітками трудових мігрантів збільшення попиту на вищу освіту сприяло розвитку галузі. Так, у західних областях, охоплених масовою трудовою еміграцією, зростання кількості вищих навчальних закладів, їх студентів та випускників відбувалося швидшими темпами [10]. Якщо ріст попиту на освіту не супроводжується потребами ринку праці, то структура та кількість випускників ВНЗ не відповідають потребам економіки. Як наслідок, значна частина населення із вищою освітою працюють в Україні не за спеціальністю.

Міжнародні перекази сім'ям емігрантів певною мірою посилюють інфляцію. Такий вплив відбувається тоді, коли перекази створюють такий попит, який вітчизняне виробництво не спроможне задовольнити. Як наслідок, зростає обмінний курс національної валюти, ростуть ціни, збільшується імпорт. У регіонах України, з яких найбільша чисельність населення емігрувала на заробітки за кордон, ціни на споживчі товари значно вищі. У 2000-х рр. в Україні саме грошові перекази з-за кордону значною мірою вплинули на стрімке й економічно необґрунтоване зростання цін на нерухомість.
Грошові перекази мігрантів надходять в іноземній валюті, що знаходить своє відображення в структурі платіжного балансу. Приватні грошові перекази за методологією платіжного балансу - це дохід домогосподарств, що надходить від інших домогосподарств з-за кордону, та головним чином пов'язані 3 тимчасовою або постійною міграцією населення [9]. У структурі платіжного балансу з приватними грошовими переказами значною мірою пов'язані дві статті: “оплата праці робітників" і “приватні трансферти”. Ці стандартні компоненти відображаються у рахунку поточних операцій. На відміну від міжнародних кредитів та іноземних інвестицій, грошові перекази не вимагають повернення. Отже, грошові перекази мігрантів 3-за кордону позитивно впливають на рахунок поточних операцій платіжного балансу країни.

Проаналізувавши статистичні дані за останні роки [9; 11], можемо стверджувати, що обсяги приватних грошових переказів в Україну перевищують обсяги міжнародних інвестицій в економіку України (рис. 2).

Домогосподарства, отримуючи додаткові доходи від тих, хто працює за кордоном, можуть вкладати їхню частину у підприємництво, збільшуючи обсяги інвестицій в економіку країни та рівень зайнятості. В. Толуб'як наголошує, що у випадку обмеженості кредитних та оборотних ресурсів грошові перекази залишаються єдиним джерелом розвитку підприємницької діяльності багатьох домогосподарств [8]. За даними проведених обстежень, лише трохи більше 8\% заробітчан вкладали кошти у відкриття чи розширення власного бізнесу. Переважно інвестували в торговельні підприємства, кафе, ресторани, готелі. Якщо додати до цього інвестиції у власне присадибне господарство, може йтися про 10-15\% зароблених за кордоном коштів, які витрачалися на ви- 


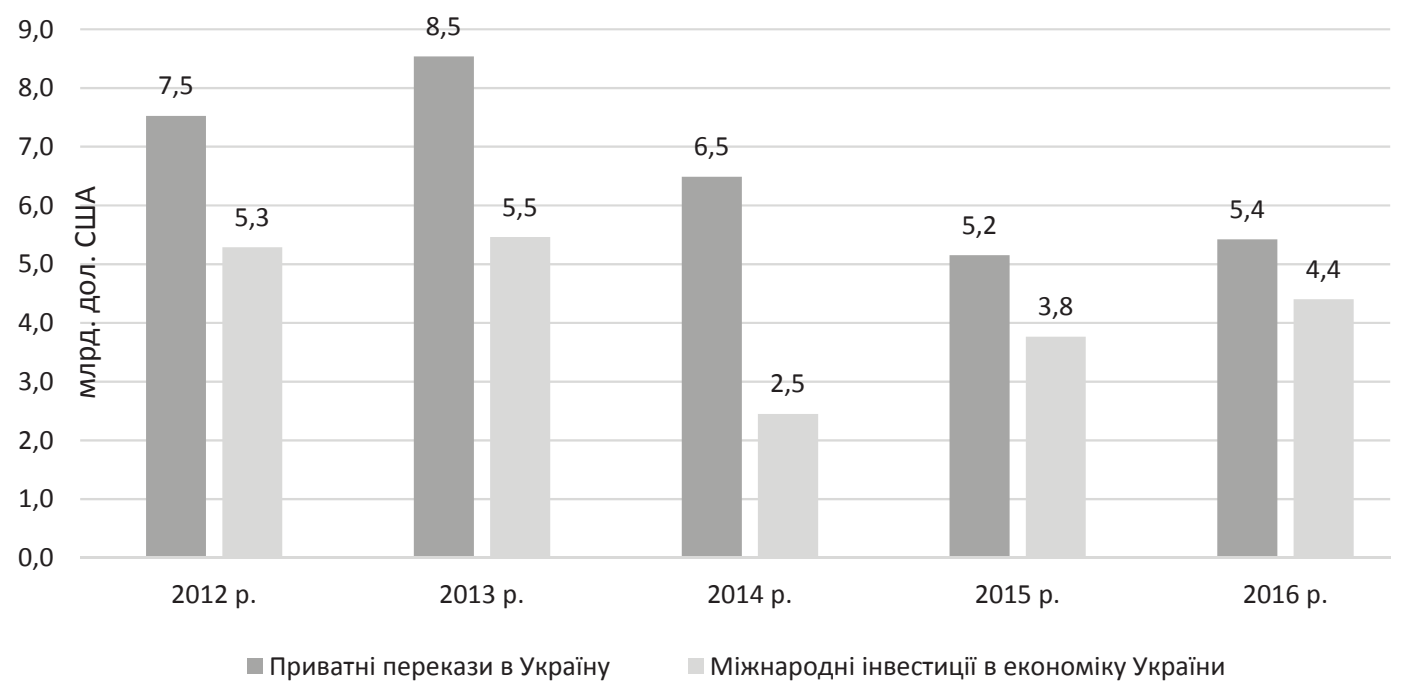

Рис. 2. Обсяги приватних грошових переказів в Україну та міжнародних інвестицій в економіку України у 2012-2016 рр.

робництво [7]. Як зазначають експерти, це обумовлено як недостатністю зароблених коштів для інвестування, так і відсутністю належних знань у сфері підприємництва. Частина мігрантів після повернення на батьківщину вже досягають пенсійного віку та не готові до провадження підприємницької діяльності.

Висновки. 3 метою підвищення стимулюючого впливу грошових переказів 3-за кордону в інтересах усього суспільства, як рушія соціально-економічного розвитку, необхідна цілеспрямована та дієва макроекономічна політика держави. Держава не може безпосередньо впливати на обсяги грошових переказів, які надходять в країну, та на ефективність їх використання домогосподарствами. Тому одним із завдань міграційної політики України має стати створення таких умов, за яких мігранти будуть зацікавлені переказувати зароблені за кордоном кошти на батьківщину. Насамперед, необхідно відновлювати довіру до української влади та вітчизняних фрінансових інститутів, зокрема банків. 3 метою пере- орієнтації потоків переказів з неофріційних каналів в офріційні необхідно здешевити послуги з переказу коштів і забезпечити належну конкуренцію на ринку фрінансових послуг. Вирішення проблем пенсійного страхування через укладання міжнародних угод забезпечить переказ зароблених за кордоном пенсій в Україну.

Лише незначна частина приватних переказів із-за кордону спрямовується на інвестиції в економіку України. Тому доцільно сприяти забезпеченню використання таких коштів на цілі інвестування, зокрема на розвиток бізнесу. Цього можна досягнути через створення сприятливих умов для ффункціонування та розвитку малих і середніх підприємств. Перспективним інструментом, на наш погляд, $є$ випуск спеціальних цінних паперів (державних та місцевих облігацій) для мігрантів й представників діаспори.

\section{Список використаних джерел}

1. Bringing about positive change for people on the move [Electronic resource]. - Access mode : 
https://www.un.org/development/desa/en/news/ population/bringing-about-positive-change-forpeople-on-move.html.

2. Международная миграция достигла рекордной отметки [Электронный ресурс]. Режим доступа : https://blogs.worldbank.org/ peoplemove/ files/newsrelease_ factbook2016_ migrationremittances_ru_1.pdf.

3. Дослідження та діалог щодо політики у сорері міграції і грошових переказів в Україні [Електронний ресурс]. - Режим доступу : http://www.iom.org.ua/sites/default/files/mom_ migraciya_yak_chynnyk_rozvytku_v_ukrayini.pdf.

4. Гайдуцький А.П. Міграційний капітал в Україні / А.П. Гайдуцький. - К. : ТОВ "Інфросистем", 2009. - 244 c.

5. Лібанова Е. Міграційні трансферти. Бідність і нерівність в Україні / Е. Лібанова // Соціально-економічні та етнокультурні наслідки міграції для України : зб. матеріалів наук.-практ. конф. - К. : НІСД, 2011. - С. 15-25.

6. Малиновська О. Перекази мігрантів з-за кордону: обсяги, канали, соціально-економічне значення : аналіт. доп. / О. Малиновська. - К. : НІСД, 2014. -60 c.

7. Малиновська О. Трудова міграція за кордон. Підмога чи шкода для економіки України? / О. Малиновська // Незалежний аудитор. - 2016. № 1-2 (48-49). - С. 136-141.

8. Толуб'як В. Трансфрерт грошових переказів трудових мігрантів як чинник соціальноекономічного розвитку України / В. Толуб'як // Світ фрінансів. - 2014. - Вип. 4. - С. 7-15.

9. Національний банк України. Оәляд приватних грошових переказів в Україну [Електронний ресурс]. - Режим доступу : https://bank.gov. ua/doccatalog/document?id=19208358.

10. Перекази мігрантів з-за кордону та можливі заходи щодо їх заохочення та ефективного використання : аналіт. записка [Електронний ресурс] / Національний інститут стратегічних досліджень. - Режим доступу : http://www.niss.gov.ua/articles/1276/\#_ftn8.
11. Прямі інвестиції (акціонерний капітал) [Електронний ресурс] / Державна служба статистики України. - Режим доступу : http://www. ukrstat.gov.ua/.

\section{References}

1. Bringing about positive change for people on the move. Available at: https://www.un.org/ development/desa/en/news/ population/bringingabout-positive-change-for-people-on-move.html.

2. Mezhdunarodnaya mihratsiya dostigla rekordnoy otmetki [International migration reached a record high]. Available at: https://blogs.worldbank. org/peoplemove/files/newsrelease_factbook2016_ migrationremittances_ru_1.pdf. [in USA].

3. Doslidzhennia ta dialoh shchodo polityky $u$ sferi mihratsii i hroshovykh perekaziv v Ukraini [Research and dialogue on migration policy and remittance policies in Ukraine]. Available at: http://www. iom.org.ua/sites/default/files/mom_migraciya_yak_ chynnyk_rozvytku_v_ukrayini.pdf.

4. Haydutskyi, A.P. (2009). Mihratsiynyi kapital v Ukraini [Migration capital in Ukraine]. Kyiv: Informsystem [in Ukrainian].

5. Libanova, E. (2011) Mihratsiyni transferty. Bidnist $i$ nerivnist $v$ Ukraini [Migration transfers. Poverty and inequality in Ukraine]. Kyiv: NISD, 15-25 [in Ukrainian].

6. Malynovska, O. (2014). Perekazy mihrantiv z-za kordonu: obsiahy, kanaly, sotsialno-ekonomichne znachennia [Transfers of migrants: volume, channels, social economic importance]. Kyiv: NISD [in Ukrainian].

7. Malynovska, O. (2016). Trudova mihratsiya za kordon. Pidmoha chy shkoda dlia ekonomiky Ukrainy? [Labour migration abroad. Willingness or harm to the Ukrainian economy?]. Nezalezhnyi audytor - Independent auditor, 1-2 (48-49), 136-141 [in Ukrainian].

8. Tolubiak, V. (2014). Transfert hroshovykh perekaziv trudovykh mihrantiv yak chynnyk sotsialno-ekonomichnoho rozvytku Ukrainy [Transfer of remittances of labour migrants as a factor of social 


\section{ФІНАНСОВЕ ЗАБЕЗПЕЧЕННЯ СТАЛОГО РОЗВИТКУ}

and economic development of Ukraine]. Svit finansiv - World of finance, 4, 7-15 [in Ukrainian].

9. Natsionalnyi bank Ukrainy. Ohliad pryvatnykh hroshovykh perekaziv $v$ Ukrainu [National Bank of Ukraine. An overview of private money transfers to Ukraine]. Available at: https://bank.gov. ua/doccatalog/document?id=19208358.

10. Perekazy mihrantiv z-za kordonu ta mozhlyvi zakhody shchodo yikh zaokhochennia ta efektyvnoho vykorystannia: analitychna zapyska [The transfers of migrants from abroad and pos- sible measures to promote and effectively. Analytical brief]. Natsionalnyi instytut stratehichnykh doslidzhen. Available at: http://www.niss.gov. ua/ articles/1276/.

11. Priami investytsii (aktsionernyi kapital) [Direct investment (equity)]. Derzhavna sluzhba statystyky Ukrainy. Available at: http://www. ukrstat.gov.ua/.

Стаття надійшла до редакції 18.08.2017. 